\title{
Research on the Development Status and Countermeasures of Network Economy in China
}

\author{
Hang $\mathrm{Gao}^{1}$ \\ ${ }^{1}$ Business School, Shandong University of Political Science and Law, Jinan, China
}

\begin{abstract}
With the rapid development of information technology, the rapid rise of the network economy has promoted the vigorous development of China's economy and become an important part of the national economy. The nature of the Internet, which spans regions and spreads quickly, has driven the transaction of products to be low-cost and efficient. These characteristics have exerted profound influence on the industrial structure in many aspects. Network economy not only changes the production mode of society through resource sharing and information exchange, but also promotes the development of social civilization. This paper analyzes the current situation of network economy and its impact on China's economic and social development, and puts forward countermeasures to promote the development of network economy.
\end{abstract}

\section{Introduction}

Network economy represents the future economic development trend and provides an efficient tool to transform information resources into economic benefits. It builds a brand-new technology platform for realizing economic growth and creates a kind of global operating environment. In China, the rapid development of the Internetwork economy has boosted the transformation of the economic growth model, promoted the upgrading and transformation of the industrial structure, and improved the social employment structure. With the advent of $5 \mathrm{G}$ era, the in-depth application of mobile internet and artificial intelligence will solve many bottlenecks in the development of network economy and play a huge role in promoting economic development. The network economy has changed and will affect human daily life and economic activities more extensively and profoundly. Although China's network economy has made great progress, it lags far behind western developed countries in infrastructure, technology guarantee, security legislation and institutional arrangements. Based on the analysis of the concept and characteristics of network economy, this paper analyzes the current situation and problems of China's network economy. In order to promote the rapid development of China's economy and society, this paper draws on the experience of foreign countries and puts forward some countermeasures to strengthen the development of network economy.

\section{Connotation and Characteristics of Network Economy}

\subsection{Connotation of Network Economy}

Network industry is an emerging industry with the rapid development of the Internet. The economic effect brought by this industry is based on the sum of economic activities caused by network media, especially the Internet. Network economy penetrates into people's life, work, study and other aspects, all-pervasive, all-inclusive. In a broad sense, network industry is the general term for all services related to the development of the Internet. In a narrow sense, network industry refers to the sum of internet-based information services.

\subsection{Features of Network Economy}

\subsubsection{Network Economy Takes Information as the Main Resource}

Network economy is mainly based on information, with information products and digital products as the leading products. Among them, digital products refer to the products that can be digitized in the transaction process with the network as the media. Information products and digital products have three important characteristics: First, public goods. Information can be used by multiple consumers without affecting the interests of any one person, so as to realize information sharing and full utilization of resources and maximize economic utility. Second, network externalities. When a product is used by more consumers, it does not reduce the utility of existing consumers, and the 
value of the product increases. Third, replicability. Digital products and information products can be copied and downloaded at low cost. As long as the reliability and authenticity of the original product is guaranteed, the production cost of subsequent products is almost zero. In essence, information includes anything that is digitized, so digital products and information products are information themselves.

\subsubsection{Network Economy is Knowledge-based Economy}

On the one hand, from the point of view of production factors, network economy has the characteristics of knowledge-based. Knowledge is a basic factor of production in network economy and an important resource to support the growth and development of network economy. A large number of products and service products provided by enterprises in network economy are knowledge-based products. The typical feature of knowledge products is interactivity, which can interact with users and provide services according to users' wishes to adapt to environmental changes. In the Internetwork economy, wealth needs to be redefined and power redistributed, both of which depend on the availability of information and knowledge. The proportion of intellectual workers in the workforce is higher than ever before.

On the other hand, information technology represented by the network is a huge driving force for mankind to enter the era of knowledge economy. With the continuous development of technology, the higher the intensity of technology and knowledge in a society and economy, the more important knowledge is in economic development. The transformation of mankind from an agricultural society to an industrial society to a knowledge-based economy is the result of the increasing importance of technology and knowledge. With the rapid development of network technology, the cost of knowledge storage and transmission is greatly reduced, and the possibility of knowledge becoming commodity is greatly enhanced, thus making knowledge economy possible.

\subsubsection{Network Economy is an Innovative Economy}

Innovation is the engine of network economy growth and the soul and essence of network economy. In the network economy supported by information network technology and communication technology, the change of technology and knowledge stock is accelerated, and the complex, changeable and constantly developing personalized consumption demand also drives the production technology to change with each passing day. It is impossible for a product to occupy the market for a long time, and for a service to meet the needs of a large number of customers for a long time. Technology and product life cycles are getting shorter and shorter, and outdated technologies will soon become obsolete. Technological imitation is faster, and competition between firms, countries and countries is more intense. In this case, only by continuing to update and actively creating new products through innovation can we not be eliminated from the competition. Applying knowledge, adding creativity and creating knowledge become the core issues of economic activities. Learning ability and creativity become the source of market competitiveness.

\subsubsection{Network Economy is a Full Time and Space Economy}

First, in terms of the time of economic activities, the network economy has no limit on working hours. Information networks are operating on an hourly basis and economic entities have access to the Internet at any time. Web-based economic activity can be continuous at any time. In addition, people in different time zones work at different hours, ensuring that there is online economic activity around the world every hour. Second, from the perspective of geographic space of economic activities, the developed telecommunications network, e-commerce and online shopping activities have greatly reduced the intermediate links in the production, circulation and consumption of products and services. The interdependence of the global economy is on the rise and the integration of the world economy is taking shape. With the establishment of transnational computer network and information superhighway, the economic system becomes more and more a global system. The boundaries between domestic and foreign economic activity become blurred, with goods, services, capital, Labour and information all moving around the globe. Thirdly, from the perspective of information resources, the Internet system has become the world's largest information repository due to its nearly unlimited information storage space. Online information from all over the world can be easily retrieved and quickly transmitted, which makes the economic connection between different regions more convenient. In addition to the above characteristics, network economy also has the characteristics of miniaturization of enterprise organizations, integration of economic activities, blurring the boundaries between consumers and producers.

\section{Development Status of Network Economy in China}

In recent years, China's Internetwork economy has developed by leaps and bounds. The extensive application of Internet technology in all walks of life has brought model breakthrough and promoted product innovation, which is the foundation of the development of network economy. As the number of Internet users increases year by year, it has become a common pattern for people to work, study and live on the Internet. By the end of 2019, the number of netizens in China had reached 904 million, with a total increase of 75.1 million netizens for the whole year. China's Internet penetration rate had reached 64.5 percent, 4.9 percentage points higher than the end of 2018. By the end of 2019, the number of Websites in China had reached 4.97 million, down 5.1 percent from the end of 2018. By the end of 2019, the number of Chinese web pages had reached 298 billion, up 5.8 percent from the end of 2018.In 2019, mobile Internet access traffic consumption had reached 122 billion GB (see Table 1). 
Table1. The foundation of network economy in China

\begin{tabular}{|c|c|c|c|c|c|}
\hline \multirow{2}{*}{ Project } & \multicolumn{5}{|c|}{ Year } \\
\cline { 2 - 6 } & 2015 & 2016 & 2017 & 2018 & 2019 \\
\hline $\begin{array}{c}\text { Netizens Scale } \\
\text { (million) }\end{array}$ & 688 & 731 & 772 & 829 & 904 \\
\hline $\begin{array}{c}\text { Internet } \\
\text { Penetration }\end{array}$ & $50.3 \%$ & $53.2 \%$ & $55.8 \%$ & $59.6 \%$ & $64.5 \%$ \\
\hline $\begin{array}{c}\text { Number Of } \\
\text { Sites (million) }\end{array}$ & 4.23 & 4.82 & 5.33 & 5.23 & 4.97 \\
\hline $\begin{array}{c}\text { Number Of } \\
\text { Webpages } \\
\text { (billion) }\end{array}$ & 212 & 236 & 260 & 282 & 298 \\
\hline $\begin{array}{c}\text { Mobile } \\
\text { Internet Access } \\
\text { Traffic (billion } \\
\text { GB) }\end{array}$ & 4.19 & 9.38 & 24.59 & 71.11 & 122.00 \\
\hline
\end{tabular}

a. The data in this table are from the National Bureau of Statistics of China

The total turnover of the network economy has also made great progress, from 817 billion yuan in 2013 to 5995 billion yuan in 2019, with annual growth rates of over $25 \%$ (see Figure 1). The role of network economy in the whole national economy is gradually emerging, showing the unique vigor and vitality of the new economic model. B2B trading, online shopping, network finance, online entertainment, network media, online education, transportation service and other subdivisions are experiencing rapid growth. The distribution structure of each subdivision area is shown in Figure 2.

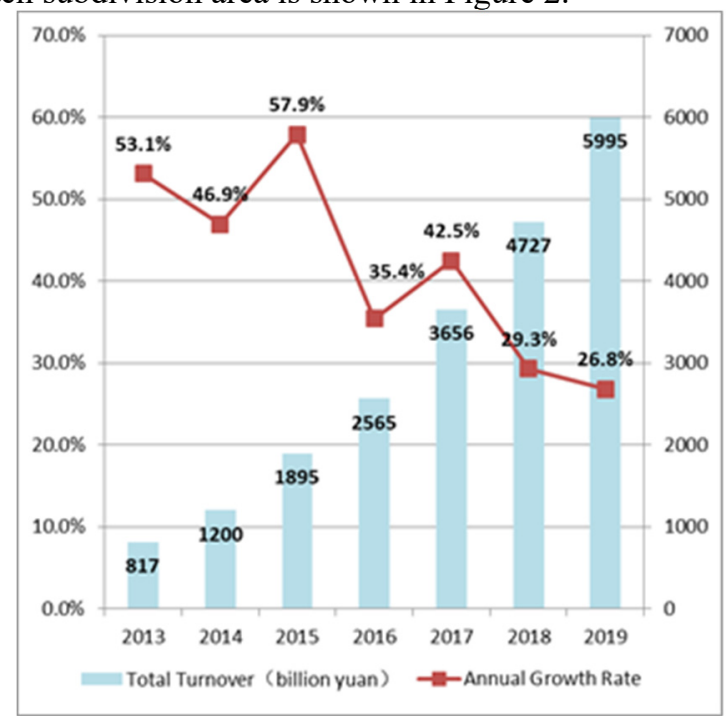

Fig1. The total turnover of network economy in China

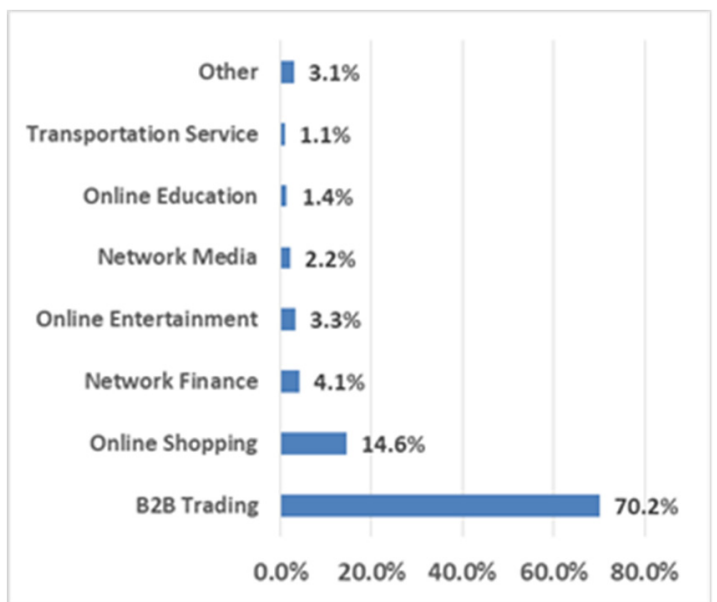

Fig2. The distribution structure of network economy of China

\section{Influence of Network Economy on Economic and Social Development}

\subsection{Accelerating the Transformation of Economic Growth Mode from Extensive to Intensive}

Network greatly improves production efficiency, circulation efficiency and working efficiency. Network simplifies the circulation of commodities, reduces office costs, saves circulation time and costs, and improves the efficiency of transactions. Network can quickly deliver valuable information to customers at the fastest speed and lowest cost. Network enables the government and enterprises to keep abreast of the investment, financing, projects and markets at home and abroad, and avoid the phenomenon of blind introduction, blind investment and blind construction. The network can enable the capital to serve for the enterprises in a very short time, in order to improve the utilization rate of capital. Network enables enterprises to obtain and utilize the latest technical information at the fastest speed, thus avoiding their own blind research. Network can promote enterprises to pay more attention to talents, so that the role of human capital and knowledge capital get more full play[1].

\subsection{Promoting the Optimization and Upgrading of Industrial Structure}

At present, the general trend of industrial structure change will be: the proportion of material production departments will decrease, while the proportion of knowledge service departments will increase. Products to the digital, networking and intelligent development trend is unstoppable, network products and net-related products will develop rapidly. The combination of network technology and other high-tech industries will produce many revolutionary products. A biochip, for example, might be placed in one part of the body according to a patient's needs, and doctors would be able to track treatment over the Internet. Network technology can be widely and deeply combined with traditional industries in China, which greatly promotes the upgrading of traditional industries. The Internet can play an important role in the 
fields of commerce, tourism, transportation, mining and surveying.

\subsection{Improving the Employment Structure}

Network economy and knowledge economy are closely linked. In this new technological revolution, human capital will be widely valued and all countries will adopt various incentives for talent. In China, there has been a big increase in internet-related employment, especially in the service sector. Under the impact of network economy, people will consciously improve their own quality to meet the requirements of social development. The worker's knowledge and new skills will increase rapidly. Industries with low requirements for knowledge and technology will gradually shrink, and the number of people employed will decrease accordingly[2].

\subsection{Providing Products and Services of High Quality and Low Price}

Due to the rapid development of technological innovation in the Internet era, the life cycle of products is getting shorter and shorter, and the prices of products and services are constantly falling. This is very conducive to controlling inflation, the real purchasing power of consumers can be greatly increased. Network can promote domestic and foreign enterprises to carry out fierce competition and constantly adopt new technologies and new processes. In this way, the potential inside the enterprise can be tapped, the price of goods and services can be greatly reduced, and the diversification of information services and other services can be promoted. Consumers can enjoy better and cheaper goods and services than in traditional economies.

\section{Countermeasures to Promote the Development of Network Economy in China}

\subsection{Strengthening Network Infrastructure Construction}

At present, the number of Internet users in China is considerable, but the development and construction of network facilities are not perfect. The popularization scope of computer technology in China is relatively small, which is not conducive to the development of network economy. Therefore, the government should focus on the long-term development of the country, improve the importance of network facilities, strengthen the construction of strategic and network infrastructure. Specifically, the government should improve the coverage of the network, narrow the differences in network development between regions, strengthen the density of mobile network base stations, and form a high-capacity, high-rate, all-coverage optical fiber transmission network. Government should formulate and implement the development strategy of network economy, actively improve the utilization rate of domestic network information, and make good preparations for the rapid, stable and comprehensive development of domestic network economy[3].

\subsection{Improving the Profit Model of Network Economy}

The development of network information is inseparable from the application of information technology and the upgrading of traditional industries. In the process of the development of network economy, we should give full play to the resource advantage of network products and combine human resources, material resources, financial resources and technology organically. This can change the traditional way of doing business, share advanced information technology as much as possible, and give full play to the role of infrastructure. The development of network economy depends on correct business model, perfect profit model and reasonable profit space. At the same time, the development of network economy should actively promote the growth of logistics enterprises, improve transportation capacity, ensure the security of capital settlement, and realize the complementary advantages between traditional and emerging industries.

\subsection{Accelerating the Construction of the Talent Team}

High-quality network economic talents should have strong analytical ability, modern technical skills and good cooperation spirit. Firstly, it is necessary to cultivate highlevel professional and technical personnel in line with the development requirements of the network economy relying on various universities. Secondly, it is necessary to strengthen the continuing education of on-the-job personnel, so that their knowledge structure and working skills can be continuously improved to meet the needs of the development of modern social network economy. Thirdly, the government should formulate good incentive policies, give more preferential policies or financial subsidies for enterprises to introduce excellent network talents, and promote the formation of a good talent reserve [4]. Finally, it is necessary to strengthen the popularization of network economy knowledge and improve the public's ability to use network economy.

\subsection{Creating a Sound Legal and Regulatory Environment}

The development of network economy cannot be separated from the support of the national legal environment. Firstly, the government should earnestly promote the implementation of the E-commerce Law, Network Security Law and other laws to reduce the operational risks of network economy. Secondly, in view of the lack of effective supervision on user information, personal privacy and other issues, the government should strengthen supervision on the network environment. The government should establish a strict normative system in online shopping, online trading and e-commerce taxation. This can not only ensure the free development of network economy, but also build a secure and stable network economy market. Thirdly, in view of the frequent 
occurrence of online credit fraud and online fraud in recent years, a strict safety supervision mechanism needs to be established [5]. The government should discover blind spots in supervision in a timely manner and introduce relevant policies to severely crack down on such phenomena as false propaganda and low online moral value.

\section{Conclusion}

Network economy is the inevitable result of the development of digital age, and its development is also changing the direction of social development. Network economy is the necessary way to transform the traditional industry, promote the upgrading of industrial structure and save social operation cost. Network economy has not only changed people's way of life, learning, working and economic activities, but also changed people's values. In the face of the challenges posed by network economy, China, as the world's largest developing country, should have a clear understanding of its shape and seize this new development opportunity in a timely manner. This paper provides some useful suggestions for promoting the development of network economy in China.

\section{Acknowledgment}

Fund: This study is funded by youth academic innovation team of management science and engineering of SDUPSL.

\section{References}

1. S. Q. Pan, "Digital economy: new engine of China's economic growth," Internet communication, vol.17, pp. 26-27, March 2020.

2. B. Chen, "Development of digital Economy and innovation of regulatory system from the perspective of rule of law," Journal of Shanghai University, vol.36, pp. 100-115,April 2019.

3. W. L. Wang, "Research on the development trend and promotion policy of digital economy in China," Economic review, vol.35, pp. 69-75, January 2019.

4. S. Y. Chen, "Network economy and its challenges to traditional economic theories ," China Logistics and Procurement, vol.40, pp. 75-76, March 2019.

5. B. Zhang, "Analysis and countermeasures on the development dilemma of network economy in China," Modern Marketing, vol.17, pp. 4-5, July 2019.

6. X. Y. Qiao, "Practical Road of Internetwork economy in China," Modern Enterprise Culture, vol.11, pp. 110-111, J uly 2018.

7. S. L. Jiang, "Digital economy leads China's innovation and development," Global market information herald, vol.23, pp. 4-9, August 2017.

8. L. Zhang, "Research on the impact of network economy on national economic development," Consumption guide,vol.58, pp. 139-140, December 2017. 